\title{
A manifestação do mítico em "O Continente l": da construção da narrativa à caracterização das personagens
}

\author{
The demonstration of mythic at "The Continent I": \\ the construction of the narrative to the characterization of the characters
}

\section{Cristiane de Oliveira Eugenio}

Universidade de Passo Fundo-UPF - Passo Fundo - Rio Grande do Sul - Brasil

\begin{abstract}
Resumo:Erico Verissimo definiu-se como um contador de histórias, sendo um dos escritores mais populares do século XX. Narrou, em $O$ Continente I, a saga sul-riograndense, não por que gostasse do regionalismo literário, mas por buscar desvendar a presença de uma vida interior naqueles habitantes da campanha. $O$ autor chegou a acreditar que aqueles homens rudes eram desprovidos de qualquer complexidade psicológica, e que, ao recriar duzentos anos de história, transformaria esses homens em personagens heróicas. Com base na forma com que Erico Verissimo escreve e representa a saga $O$ Tempo e o Vento, este artigo tem como ponto de pesquisa o eixo temático que vai balizar as características dos homens e seus comportamentos dentro da narrativa, conduzindo o estudo de $O$ Continente $I$, de sua construção, e de seus principais personagens, à luz da mitologia. A análise tem como fundamentação a forma utilizada por Erico Verissimo à construção da saga e o papel das personagens, mesclando história e ficção. Assim, como matéria literária, seu caráter mítico oferece um leque de possibilidade de análise, especialmente, a imbricação entre história e literatura. Tal análise tem como principais objetivos identificar a existência de relação entre a mitologia regional e universal no romance de Erico Veríssimo, identificando os momentos em que a narrativa histórica e mitológica estabelecem um caráter dialógico, dessa forma, conduzindo a observação de possíveis traços e objetos que façam a referência dos principais personagens de $O$ Continente $I$ com o universo mítico. A compreensão do mito na sociedade não é apenas tornar real uma etapa na história do pensamento humano, mas compreender a que contemporaneidade eles estão ligados, e identificar em que momento as manifestações, consideradas por alguns como exageros, devem ser reconhecidas como fenômenos humanos, pois somente quando se considera essas condutas sob a perspectiva histórico-religiosa é que essas formas poderão se revelar como fenômenos de cultura.
\end{abstract}

Palavras-chave:Literatura. Mitologia. Simbologia. Narrativa. Personagem.

Abstract: Erico Verissimo was defined as a storyteller, one of the most popular writers of the twentieth century. Narrated in The Continent I, south of Rio Grande saga, not because he liked the literary regionalism, but seek to unravel the presence of an inner life in those inhabitants of the campaign. The author came to believe that those rough men were devoid of any psychological complexity, and that, to recreate two hundred years of history, these men become heroic characters. Based on the way that Erico Verissimo writes and is the saga Weather and Wind, this article takes as its point of research the main theme that will delimit the characteristics of men and their behavior within the narrative, leading the study of the Continent I of its construction, and its main characters, in the light of mythology. The analysis is reasoning the form used by Erico Verissimo the construction of the saga and the role of characters, blending history and fiction. Thus, as a literary matter, its mythical character offers a range of possibilities for analysis, especially the overlap between history and literature. This analysis has as main objective to identify the existence of a relationship between regional and universal mythology on the novel by Erico Verissimo, identifying the times when the historical 
narrative and mythological establish a dialogical character, thus leading to observation of possible features and objects make reference to the main characters of The Continent I with the mythical universe. The understanding of myth in society is not only realize a stage in the history of human thought, but understand that nowadays they are attached, and identify at what point the demonstrations, considered by some as exaggerations, should be recognized as human phenomena, because only when it considers such conduct under the historical-religious perspective is that such forms may prove to be phenomena of culture.

Keywords: Literature. Mythology. Symbology. Narrative. Character.

\section{Introdução}

O presente artigo objetiva realizar um estudo em que se concebe o mito como uma narrativa de caráter simbólico, a qual constitui saberes e ideologias que estabelecem a construção de conhecimentos filosóficos, históricos e literários, relacionando-se a conceitos estabelecidos sobre o real e o ficcional, o sagrado e o profano, construindo assim, uma abordagem diacrônica entre mitologia e literatura.

A concepção da análise dar-se-á com base em estudos de pesquisadores, os quais definem o mito como uma explicação da realidade, fenômenos naturais, acontecimentos da vida e origem do mundo, em contraponto com filósofos, religiosos e dicionaristas, que acreditam ser o mito um presuposto para lições de moral baseadas em fábulas e histórias irreais.

Embora uma das características do mito seja estar estabelecido em um tempo antigo "fabuloso", pode-se perceber a manifestação dele nos romances modernos, apresentando, por exemplo, visões mitológicas da mulher ou fábulas dotadas de complexidades mitológicas, com seus feitos, heróis e anti-heróis, tentando explicar a origem do homem e o comportamento do ser humano.

Baseado no fato de que o mito pode ser identificado na arte literária, tornando o mundo real diante do imaginário em diferentes contextos, é que se estabelece o eixo temático de pesquisa, analisando a forma, a qual Erico Veríssimo se apropria, na obra $O$ Continente $I$, para a construção da mitologia regional e universal, a fim de montar uma narrativa que, de um lado reconta, do ponto de vista literário, a história do Rio Grande do Sul, de outro, apresenta personagens heróicos que estabelecem relação com complexidade mítica.

\section{Centauro dos pampas: a construção da mitologia sul-rio-grandense}

São muitos os críticos que afirmam a impossibilidade de se analisar o povo gaúcho sem conhecer a etimologia da palavra que define o termo "gaúcho". No entanto, como afirma Reverbel (1986, p.5-7), nem mesmo os etimologistas se entendem a respeito da origem da palavra "gaúcho" e, ao que tudo indica, jamais se entenderão. $O$ escritor considera que ninguém sabe ao certo se o vocábulo é de origem indígena ou se foi uma palavra europeia adaptada a um fato americano. Assim, abre-se um espaço para diversas hipóteses, conjecturas e palpites. A grande maioria dos estudiosos trata o assunto como irrelevante, já que o verdadeiro interesse não é a etimologia da palavra, muitas vezes de origem pejorativa, e sim o gaúcho como expressão social, cultural e histórica.

Reverbel (1986, p. 69) diz que o gaúcho apareceu, na sua feição primitiva, em terras do Rio do Prata e que seu aparecimento no Rio Grande do Sul aconteceria bem mais tarde através de fatores como pastagem abundantes e enormes rebanhos sem dono, já que o povo gaúcho, na origem, caçava gado, andava a cavalo, tomava chimarrão em um espaço muito amplo, criando-se, no então continente de São Pedro, três tipos de gaúchos: o argentino, o uruguaio e o sul-rio-grandense.

Esses três tipos sociais possuíam muitos traços em comum, como o culto ao cavalo e o boi, a carne assada, o mate amargo, o couro e o sebo ( representando o início de sua atividade econômica) e 
o contrabando. Essas características comuns também apresentavam pontos inexplicáveis, como o fato dos três tipos de gaúchos serem refratários a montar em éguas, o que Reverbel (1986, p. 70), galgado em estudos de Francisco de Aparício, diz ser uma das superstições mais inexplicáveis do gaúcho sul-rioplatense.

Conforme Reverbel (1986, p. 84-88), o gaúcho primitivo é constituído da mestiçagem entre espanhóis, portugueses e índios. Entre as heranças portuguesas e espanholas recebeu o cavalo - mais tarde, por ser inseparável ao animal, seria chamado por alguns escritores como "centauro dos pampas" herdou também a faca, utensílio de grande importância para o cotidiano do gaúcho e objeto simbólico utilizado por Erico Verissimo. Do índio ficou a boleadeira, o poncho, o mate, dentre outros, além do linguajar que iria completar o dialeto com influências portuguesas, espanholas e negras. Como já citado, a palavra gaúcho possuía, muitas vezes, sentido pejorativo, o qual só o foi mudar quando, esse homem de feições e comportamento primitivo, deixou de ter conotação de gaudério, marginal, passando a ser visto como campeiro, hábil no campo e bom soldado.

Já Erico Verissimo (1976, p. 296) conclui, após reflexão sobre a criação de um dos mais famosos personagens, Capitão Rodrigo Cambará, que é quase impossível responder como os "tipos gaúchos", como o próprio personagem, são criados, pois eles são óbvios e inevitáveis. O problema seria como aceitar a inevitabilidade do óbvio sem cair no estereótipo, arremata, dessa forma, dizendo que

A palavra gaúcho está associada em nosso espírito a termos como macho, bravo, violento, mulherengo, aventureiro, nobre, generoso...Talvez eu não esteja muito longe da verdade se disser que, antes de ter corpo e nome, o Capitão Rodrigo era uma ideia no meu cérebro - de certo modo o símbolo de uma rude estirpe e duma era áspera. Às vezes, leitores me perguntam que pessoa da vida real me serviu de modelo para essa personagem, e eu respondo com a maior sinceridade que o marido de Bibiana deve ser um tipo compósito, produto de maquinações do inconsciente.
Ainda refletindo sobre a visão que tinha dos homens gaúchos, quando ainda, segundo ele, era um "moço que vivia do mundo do faz-de-conta" Erico relata, em Solo de Clarineta, (1976, p. 289-291) um episódio familiar que o faria repensar sobre a condição deste homem rude que ocupava os campos do sul do país. Erico conta, que em uma tarde de chuva, em fins de 1930, quando seu tio Tancredo chega à casa de seu avô Aníbal, senta-se no sofá em cima de um de seus discos de Beethoven, e após os hábitos de costumes daquele típico homem rude, Erico conclui, como o próprio escreve: "Faltava aos nossos 'guascas' densidade psicológica, esse tipo de conflito capaz de produzir drama. Sobre homens assim vazios - concluí então, levianamente - era impossível escrever um romance que tivesse caráter e nervo." O escritor, completa que, passados quinze anos, reexaminava o episódio e decidia que cabia ao romancista descobrir como eram "por dentro" os homens da campanha, "Era com aquela humanidade batida pela intempérie, suada, sofrida, embarrada, terra-a-terra, que eu tinha de lidar quando escrevesse o romance do antigo Continente. Talvez o drama de nosso povo estivesse exatamente nessa ilusória aparência de falta de drama."

Neste capítulo tenta-se estabelecer a relação entre a construção da mitologia sul-rio-grandense, desde os tempos mais primórdios, onde o termo "gaúcho" era usado para rotular e identificar personagens "tipos" da realidade em âmbito social, cultural, histórico, e folclórico. Salientando ainda termos históricos que recontam a época em que os valores que constituem, hoje o que chamamos de mito, e que está presente no imaginário popular, estavam sendo construídos, como exemplo, toma-se o termo "centauro dos pampas" usado para intitular o capítulo, que faz alusão a um ser híbrido da mitologia, parte homem, parte cavalo, uma das formas mitológicas criadas para dar nome ao gaúcho enquanto guerreiro, embora o gaúcho "centauro dos pampas" ou "monarca das coxilhas" nunca tenha existido, seja apenas uma criação, como alguns críticos dizem - intelectual, já que ele deva ser percebido, distante do universo ufanista, como 
alguém que cria o gado e trabalha a cavalo ou trabalha para quem cria o gado.

\subsection{De Blau Nunes a Rodrigo Cambará: uma visão da literatura Sul-Rio-Grandense}

Além da mestiçagem racial e étnica, a literatura sul-rio-grandense também é composta por fatores intelectuais e culturais importantes, os quais iriam caracterizar o gaúcho como centauro dos pampas. Criou-se assim, uma possibilidade de paralelo comparativo ao que o estudioso da literatura sul-riograndense Marobin (1995, p.266) costuma dizer que, mesmo Erico Verissimo retratando, com esmero, a face externa da realidade gaúcha, não pode ser considerado um escritor essencialmente regionalista a exemplo de outros, como Simões Lopes Neto, Alcydes Maya, Roque Callage, porque há, no conjunto de sua obra, o equilíbrio entre o regional e o universal.

Nascido no Rio Grande do Sul, mas tendo estudado no Rio de Janeiro para Medicina, Simões Lopes Neto, cria uma personagem singular, Blau Nunes, que ora personagem, ora narrador, ultrapassa o tipo regional e vem assumir as características essenciais do gaúcho. Em um só paradigma, essa invenção prodigiosa de Simões Lopes Neto constitui um personagem literário imaginário, traçando um paralelo entre o regional e o universal, trazendo à tona lendas, contos e poemas que expressam um universo regional típico. Assumindo a posição de um dos maiores escritores regionalistas gaúcho, Simões Lopes Neto, dá vida ao um cidadão que representaria - gaúcho de qualquer latitude, com características romanescas do estereótipo do homem sadio, leal e ingênuo, impulsivo na alegria e na temeridade, precavido, perspicaz, sóbrio e infatigável; e dotado de uma memória de rara nitidez, fazendo uso, ainda de um incomparável dialeto gauchesco. Ao transpor as características de gaúcho estereotipado para Blau Nunes, Simões Lopes Neto cria a possibilidade de verossimilhança da vida do gaúcho. Sobre o narrador e personagem, Blau Nunes, Chaves ( 1987, p. 23) faz as seguintes considerações: "Até surgir, em 1949, O
Continente de Erico Verissimo, ele constitui a única personagem oferecida pela ficção rio-grandense ao contexto maior da literatura brasileira. Não há nenhum outro caso no qual a força da ficção tenha logrado impor à realidade a existência de uma criatura imaginária e sua visão de mundo".

No tocante a essa construção literária pode-se citar as considerações de Azevedo (2001, p. 35), "a identidade do gaúcho é uma construção intelectual com origem na literatura rio-grandense e em autores como Caldre e Fião, João Simões Lopes Neto e Erico Verissimo". A imagem que se faz de "gaúcho" tem como alicerce as percepções do passado, onde o ambiente rural e os fatos históricos mostram a nostalgia e a sensação de que antes era melhor. Essa imagem de "bairrismo" pode criar uma representação falsa de si mesmo. Para o autor, esse exagero de orgulho e confiança dos gaúchos para com os gaúchos não significa uma realidade e sim, um desejo de realidade, pois é assim que eles gostariam que fossem, assim que se sentem.

O desejo de realidade, fomentado pela nostalgia exacerbada, permite que uma linha tênue seja traçada, estabelecendo uma polarização entre o gaúcho de ontem e o gaúcho de hoje. A ideia do gaúcho do passado foi construída em fatos históricos moldados pela epopeia da literatura, ou seja, os fatos são recontados mais nobres do que deveras foram. Os homens são mais heróis do que a condição em que viviam lhes permitia ser. Em contraponto ao gaúcho tipo do passado, temos o gaúcho dos tempos de hoje, o que consegue refletir sobre sua própria condição, que está mais aculturado, e passa a não ver o personagem mítico como um Deus, e sim como um homem comum que foi enobrecido pela cultura popular.

Deparando-se com sua própria imagem frente ao espelho, o gaúcho de hoje consegue analisar esse personagem dos pampas, que foi montado e moldado para representar uma época de guerras econômicas, rudezas e poucos recursos. Em uma tentativa de preservar a memória de todas essas grandes cruzadas enfrentadas, não por dois ou três homens, mas por todo o povo sulino, o qual viveu em 
descampados expostos às vontades do tempo, é que se criou uma malha mítica que foi ocultando alguns fatos e exagerando outros. Não se pode negar a existência de virtudes possuídas por esse povo secular, como a bravura, o idealismo, a fibra guerreira e a coragem, no entanto, tem de se analisar os motivos que as desenvolveram, como a necessidade de lida de campo e o envolvimento político.

Esse perfil do gaúcho mítico, personagem da memória, aos olhos da literatura é uma criação representativa, como a personagem Capitão Rodrigo, criação de Erico Verissimo que tinha amor incondicional à liberdade, aos exageros, as mulheres, as batalhas, e que embora fosse o oposto de Blau Nunes, por exemplo, se tornou uma espécie de síntese do estereótipo gaúcho, assim como este, pois provocava catarse no leitor, merecendo um capítulo inteiro, em O Continente I. Como Blau, Rodrigo era falante, no entanto, fanfarrão, altivo e provocante. Comparando Capitão Rodrigo Cambará , ao personagem gaúcho atual, galgado no patriotismo libertário que era nato à Capitão Rodrigo, percebemos que o "gaúcho" do século XXI possui epopeia decadente, ele é o gaúcho marginalizado, à margem da sociedade, o anti-herói, psicologicamente gêmeos ou sósias do da personagem O Tatu, de Donaldo Schüller.

Essa literatura regional e mítica, que transforma homens do campo em heróis, quase fantásticos, é devido à necessidade de sobrevivência do mais forte. Quando relacionada à teoria da evolução do naturalista Charles Darwin, na obra Sobre a Origem das Espécies por Meio da Seleção Natural ou a Conservação das Raças Favorecidas na Luta pela Vida, ensina que pela seleção natural, as condições ambientais determinam o quanto uma determinada característica ajuda na sobrevivência e na reprodução de um ser vivo. Assim é que se entende como a personalidade do gaúcho foi forjada. Baseado nisto é que se contesta os personagens heróis, já que o gaúcho real vivia em condições que não propiciavam tamanho sentimentos puramente nobres e humanitários, uma vez que a lei era a luta pela sobrevivência em uma terra, por exemplo, em que o gado não tinha dono, e os que os caçassem passavam a pertencê-lo.

Assim, conforme visto, os nexos - revelando pontos em comum através do mito - estabelecidos entre grandes personagens da literatura sul-riograndense, como Capitão Rodrigo Cambará e Blau Nunes se resumem em uma tentativa de estereótipo de representação regional, personagens tipicamente folclóricos, valentes, altivos, patriotas e libertários, que conseguem conquistar simpatia de outros personagens e dos leitores, Blau com sua irreverência, e sabedoria e Rodrigo como patriarca da dinastia dos Terra-Cambará, com seu perfil intrépido, mulherengo e irresponsável, personagens estes que em contraponto com a relação que se estabelece entre o gaúcho mítico e moderno acabam por integrar-se a ideia de "bairrismo", ou seja, a personificação que se faz dos personagens representantes da literatura regional em $O$ Continente I, como o Capitão Rodrigo, pode criar um representação falsa de mundo, já que esse orgulho que se desenvolve de personagens fictícios são uma tentativa de representação, o que nos faz retomar algumas ideias teóricas de mito, a qual oculta alguns fatos e exagera outros, ou ainda que busca utopicamente idealizar um personagem fictício e inexistente como uma necessidade inata humana, tentando entender e interpretar sua existência em uma realidade antropologicamente fundamental.

\subsection{A influência do Romance de $\mathbf{3 0}$ na produção ficcional literária brasileira e regional}

Embora mais clara a concepção de gaúcho como personagem literário, mítico e histórico, ao se tomar como pauta a análise do romance $O$ Continente I, de Erico Verissimo, ainda faz-se necessário o estudo desta obra sob a ótica do Romance de 30, posto que esse período literário, como conceito, é estudado de forma pouco rigorosa. Assim, embora não possa ser delimitado e definido de forma clara, há de se admitir que o romance de 30 marcou, de forma significativa, a literatura brasileira. Neste período, as obras ficcionais são muito semelhantes entre si, fator 
que contribuiu significativamente à consolidação de obras altamente significativas no conjunto da literatura brasileira.

Iniciando com a edição da obra: A Bagaceira, de José Américo de Almeida, esse movimento tinha como romancistas: Graciliano Ramos, Jorge Amado, Erico Verissimo, José Lins do Rego, Cyro Martins, Raquel de Queiroz, Ivan Pedro de Martins e Aureliano de Figueiredo Pinto. Segundo Dacanal (1982, p.11), esse grupo não era homogêneo, nem bem definido, mas produzia obras de temática agrária, sendo por isso, também chamado de regionalistas de 30 ou neorealistas.

Em conformidade com o que afirma Dacanal (1982, p.12), pode-se dizer que, mesmo tendo como característica a produção de obras cujas temáticas são agrárias, os autênticos regionalistas de 30 também escreviam obras de temática urbana (reforçando a imprevisibilidade do conceito), entre os quais Graciliano Ramos, Jorge Amado e Erico Veríssimo, respectivamente autores das obras Angústia, São Jorge dos Ilhéus e O resto é silêncio!

O período tem como obras-núcleo O tempo e o Vento, de Erico Veríssimo, São Bernardo, de Graciliano e Os Ratos, de Dyonélio Machado, apresentando características que, segundo Dacanal (1982, p. 12), poderiam ser citadas sete, sendo que as três acima seriam as de natureza técnica e as demais de natureza temática.

Segundo Dacanal (1982, p.13), o romance de 30 se atém à verossimilhança, ou seja, o narrado é semelhante à verdade. Ele diz que a forma narrativa de Erico correspondente a este período segue à risca a tradição da ficção realista/naturalista europeia e brasileira, isto é, são as do mundo real, não havendo a intervenção de forças divinas e diabólicas. É um "um mundo laicizado".

Sobre o regionalismo, citando grandes nomes, Erico Verissimo (1976, p. 288), no primeiro volume de Solo de Clarineta, faz as seguintes considerações sobre o gênero

Apesar de ser descendente de campeiros, sempre detestei a vida rural, nunca passei mais de cinco dias numa estância, não sabia e não sei ainda andar a cavalo - para escândalo e vergonha de meu avô Aníbal desconhecia e ainda desconheço o jargão gauchesco. Embora admire os trabalhos isolados de escritores como Simões Lopes Neto, Darcy Azambuja, Ciro Martins e Vargas Neto, nunca morri de amores pelo regionalismo e, para ser sincero, tinha e ainda tenho para com esse gênero literário as minhas reservas, pois acho-o limitado e, em certos casos, com um certo odor e um imobilismo anacrônico de museu.

No que se tange às estruturas narrativas, segundo Dacanal (1982, p.13-14), o romance de 30 é fundamentalmente linear, ou seja, o lugar que os eventos narrados ocupam na narração corresponde cronologicamente com sua ocorrência. Conforme o autor, é importante que se faça uma ressalva quanto essa linearidade, pois em O Tempo e o Vento, por exemplo, essa característica é rompida. No entanto, esse fato não impede que obras como a citada possam ser definidas como "histórias com início, meio e fim".

A característica que faz referência à linguagem das personagens dos romancistas de 30 , segundo Dacanal (1982, p.14), tem como plano de fundo o fracionamento sócio-econômico cultural do país, ou seja, "é escrito em uma linguagem filtrada pelo chamado 'código culto' urbano".

Na mesma obra, Dacanal (1982, p.14), afirma que o romance de 30 estabelece estruturas históricas que podem ser identificadas com facilidade, devido as suas características econômicas e sociais. Ainda completa que os personagens compõem essas formas de estrutura, geralmente agrárias, lutando contra elas ou sendo suas vítimas, criando uma realidade que fará parte integrante do enredo.

Quanto às características políticas, sociais e econômicas, Dacanal (1982, p.15) afirma que esses autores têm uma crítica que se baseia na ideia de que a desordem reina no mundo, mas que o caos pode ser ordenado através de indivíduos ou pela ação positiva de grupos sociais. Neste sentido, o Romance de 30 está impregnado de um otimismo que poderia ser qualificado de 'ingênuo'. A ideologia da crença de que se há violência, miséria e conflito no mundo, tudo isso pode ser eliminado, porque ele é compreensível, 
segundo o teórico, a ideia tornou-se um dos motes marcantes das grandes obras do romance de 30 .

Após discorrer sobre todas as características que definem o romance de 30 e suas respectivas obras, Dacanal (1982, p.48) conclui que se a obra São Bernardo pode ser considerado a súmula em que se concentram todos os aspectos do período, a obra O Tempo e o Vento, de Erico Veríssimo, pode ser classificada como a mais característica do romance de 30 em termos de amplitude temática. Para o autor, a trilogia de Verissimo foi a única tentativa a abranger globalmente, no tempo e no espaço, uma destas zonas agrárias, onde se pode reconhecer a tentativa de recontar a formação histórica e geográfica do Rio Grande do Sul, pois estava alicerçada em aspectos que vão para além do regionalismo local, a uma visão universal.

Para que a análise da trilogia seja possível, faz-se necessário a observação de alguns elementos que nem sempre estão expostos na mera superfície do texto, e sim intrínsecos no desenrolar de toda a narrativa. Para Dacanal (1982, p. 50), a obra de Erico Verissimo tem como eixo central o auto-elogio exaltado e melancólico do patriarcado sul-riograndense. Conta a história de um Continente, sob a perspectiva dos gaúchos, através de uma mitologia que ainda se encontra arraigada no Estado, a qual vem auto-justificar a ideia de gaúcho heróico, por exemplo. Assim, os elementos fundamentais que constituem $O$ Tempo e o Vento já se encontravam racionalmente estruturados. Eles integravam o que se poderia chamar de o momento máximo da consciência política das elites sul-rio-grandenses no século passado. Conforme o Dacanal (1982, p. 5254), em O Tempo e o Vento os eventos narrados vão decaindo quando se identificam com a verdade factual. Do índio, sobraram seus descendentes, e os gaúchos heróicos começam a ser expulsos do campo, após terem se tornado escravos das revoluções. Grandeza épica esta que vai desaparecendo a partir do terceiro volume de $O$ Tempo e o Vento, posto que Erico Verissimo, após ter contribuído para o panorama literário brasileiro com o Tempo e o Vento, produz, o que muitos estudiosos, como o próprio Dacanal, chamam do "produto de sua crise completa como romancista".

\section{Mitologia e simbolismo nas obras de Erico Verissimo}

Pode-se conceber o mito como uma narrativa de caráter simbólico, que constitui saberes e ideologias as quais estabelecem a construção de conhecimentos filosóficos, históricos e literários, relacionando-se a conceitos estabelecidos sobre o real e o ficcional, o sagrado e o profano, construindo assim, uma abordagem diacrônica entre mitologia e literatura.

Alguns estudiosos insistem em definir o mito como uma explicação da realidade, fenômenos naturais, acontecimentos da vida e origem do mundo, enquanto outros, filósofos, religiosos e dicionaristas, acreditam que o mito serve como presuposto para lições de moral baseadas em fábulas e histórias irreais.

Embora uma das características do mito seja estar estabelecido em um tempo antigo "fabuloso", pode-se perceber a manifestação dele nos romances modernos, apresentando, por exemplo, visões mitológicas da mulher ou fábulas dotadas de complexidades mitológicas, com seus feitos, heróis e anti-heróis, tentando explicar a origem do homem e seu comportamento na sociedade.

Mas para que se possa entender como se constrói a malha mítica que cerca o tipo gaúcho desde os tempos primordiais, é necessário conceber que não foi o momento histórico que fez com que o mito se manifestasse. Para Eliade (1972, p. 08-19), compreender o mito na sociedade não é apenas tornar real uma etapa na história do pensamento humano, mas compreender a que contemporaneidade eles estão ligados. Completa, dizendo que as manifestações, consideradas por alguns como exageros, devem ser reconhecidas como fenômenos humanos, pois somente quando se considera essas condutas sob a perspectiva históricoreligiosa é que essas formas poderão se revelar como fenômenos de cultura. Todavia, essa experiência de 
religiosidade se apresenta, pois há uma distinção da experiência da vida cotidiana, ou seja, deixa-se de existir no mundo de todos os dias e penetra-se no mundo transfigurado.

Para o estudioso, a principal função do mito é revelar modelos exemplares de todos os ritos e atividades humanas significativas, como o trabalho, educação, arte ou sabedoria. Esses modelos e atividades abrem um viés de análise que pode relacionar à previsibilidade do homem sulino, já que todos desempenhavam funções repetidas por seus contemporâneos como, por exemplo, as lidas de campo, as carreteadas e as guerras que marcavam o destino dos homens da família Cambará, já que a personagem Capitão Rodrigo fazia questão de dizer que Cambará macho não morria na cama, mas na guerra.

Consoante ao que afirma o autor, a relação entre o homem e o mito se dá através dos símbolos, que serve como meio de comunicação entre eles, uma vez que o mundo lhe fala através de suas estrelas, estações e noites, cujos homens respondem através de seus sonhos e de sua vida imaginativa.

Dessa forma, é mister considerar também a teoria de que o mito revela modelos exemplares de sabedoria, conforme a expressão cunhada por Ana Terra, e herdada por Bibiana (VERISSIMO, 2004, p.189) "Noite de ventos, noite dos mortos.", significando a morte anunciada por um vento agourento, quando os elementos da natureza estabelecem ambiências com o homem, sendo que ele corresponde através de sua capacidade de criar situações, expressão essa que é transmitida através das gerações como sabedoria, transformando o absurdo em significação e dando sentido ao imaginário.

\section{Para Mircea}

[...] Embora os protagonistas dos mitos sejam geralmente Deuses e Entes Sobrenaturais, enquanto os dos contos são heróis ou animais miraculosos, todos esses personagens têm uma característica em comum:eles não pertencem ao mundo quotidiano[...]. Tudo o que é narrado nos mitos concerne diretamente a eles, ao passo que os contos e as fábulas se referem a acontecimentos que, embora tendo ocasionado mudanças no Mundo [...], não modificaram a condição humana com tal. (1972, p. 15)

O autor ainda afirma que a história narrada pelo mito constitui um conhecimento de ordem esotérica, onde conhecer a origem de um objeto, de um animal ou planta, seria equivalente a adquirir sobre eles um poder mágico, semelhante às histórias bíblicas contadas por Pedro Missioneiro sobre o que teria acontecido com a mulita e Nossa Senhora, o que definiria a reprodução do animal que só tem filhotes de um sexo em cada ninhada. Ao relacionar mitologia a romance, Eliade (1972, p.164) completa que "O romance não tem acesso ao tempo primordial dos mitos; mas, na medida em que conta uma história verossímil, o romancista utiliza um tempo aparentemente histórico (grifo do autor) e, não obstante, condensado ou dilatado, um tempo que dispõe, portanto, de todas as liberdades dos mundos imaginários".

Tangente ao surgimento de deuses como protagonistas de histórias míticas através de questionamentos como a origem do mundo, de plantas, animais, ações da natureza, respondidos através de intuições ou suposições, tem-se a manifestação religiosa, com origem em um pensamento mágico, como podemos claramente observar nos primeiros capítulos de O Continente I.

Algumas das teorias vêm ultrapassando séculos de história, ensinando que essas manifestações tenham sido fomentadas por terem surgido em tempo de grandes batalhas em que os primeiros deuses eram adorados em sua sabedoria, poder e violência, como os deuses do Olimpo: Zeus e Cronos, ambos maldosos e vingativos, mas sempre amparados por deuses benévolos, como Atena, deusa da Paz e Demeter, a grande-mãe. A partir daí, perpetuam-se vários mitos, alguns muito populares, tidos como verdade absoluta, alicerçados no culto ao divino, ao cristão, afirmam a tradição de que toda criação acaba sendo o verbo, a palavra, como por exemplo: "faz-se a luz e a luz se fez".

Dentre eles podemos citar o mito que explica a origem do mundo; o mito de Adão, Eva e a serpente - 
argumentando sobre toda a origem do sofrimento humano como penitência ao pecado original; e o da maçã - representando o mito do proibido, do pecado e já iniciando uma carreira de simbologia que iria se atrelar ao fruto, ao qual podemos fazer inferência do conto de A Branca de Neve, onde uma maçã também representaria a maldade, o pecado. Bem como afirma Mircea

[...] o mito é uma realidade cultural extremamente complexa, que pode ser abordada e interpretada em perspectivas múltiplas e complementares [...] o mito conta uma história sagrada, relata um acontecimento que teve lugar no tempo primordial, o tempo fabuloso dos começos [...] o mito conta graças aos feitos dos seres sobrenaturais, uma realidade que passou a existir, quer seja uma realidade tetal, o Cosmos, quer apenas um fragmento, uma ilha, uma espécie vegetal, um comportamento humano, é sempre portanto uma narração de uma criação, descreve-se como uma coisa foi produzida, como começou a existir [...].(1963, p.12-13):

Ao buscar conhecimento através da ciência, da história - às perguntas com registro, provas do que aconteceu, das manifestações do mundo e das pessoas, o homem usa o mito - o lado emblemático das grandes manifestações, descobrimentos e tragédias, a parte obscura de tudo - como tentativa de responder aos seus próprios questionamentos, em uma espécie de auto-argumentação. O mito passa, dessa forma, de necessidade religiosa, invenção dos grandes deuses do Olímpo, para estudo científico, a partir do qual se pode reconhecer particularidades de cada cultura

Dessa forma, este capítulo traz algumas das imbricações do mito constituído através de uma realidade complexa, contando uma história sagrada ou que tenha início no tempo primordial, o tempo fabuloso dos "começos", contanto feitos sobrenaturais a partir de uma realidade que passou a existir, como uma espécie de mediação simbólica entre o sagrado e o profano. Esses mitos teogônicos, os quais possuem contexto religioso, como as estórias bíblicas contadas por Pedro Missioneiro, Ana Terra ou Bibiana, e em toda a narrativa de O Continente em uma tentativa de justificar a realidade transcendendo o senso comum ou a razão, convertem-se assim em fábula ou ficção, transferindo às personagens um aspecto de sabedoria e experiência de vida, ou simplesmente respondem aos seus próprios questionamentos.

\subsection{Erico Verissimo e o mito do contador de histórias}

Erico Verissimo definiu-se como um contador de histórias, justamente porque contar a história é um ato do homem solidário, originase na observação rigorosa do real, captando-o em sua essencialidade, e visa a problematizálo, tanto na perspectiva do narrador, quanto sob a do leitor.

Flávio L. Chaves

Se os romances nascem também para resgatar as realidades que estão se perdendo, Erico Verissimo, despontado no painel literário ao publicar em 1932 a obra infanto-juvenil Fantoches, em 1933, Clarissa, definiu seu dom de contador de histórias em 1934, publicando Caminhos Cruzados.

Desempenhou seu papel como romancista, pois segundo Zilberman (1992, p. 72-74), o autor "narrou como poucos, a decadência e a morte das sociedades". A escritora, após estudar trinta anos a produção verissimiana, conclui que o autor contou histórias sobre as problemáticas das grandes famílias, o apogeu político, a decadência interna familiar, a contestação de grupos hegemônicos por setores emergentes e o conflito dos grandes impérios, mais intensamente nas obras Música ao longe, 0 Tempo e o Vento, Incidente em Antares e $O$ Prisioneiro respectivamente. Afirma também que Erico Verissimo não narrava as decadências para lamentá-las, tampouco para comemorar a queda dos que perdiam o poder, mas situava seus romances em uma zona de transição, onde os lugares sociais estavam sendo trocados. A pesquisadora considera que o escritor apresenta ao leitor a transformação e o aparecimento do novo, conferindo à narrativa inegável natureza histórica, estabelecendo relação de suas obras com o romance histórico, gênero esse, ao qual se dedicou. 
Tangente ao posicionamento do autor frente aos problemas políticos, sociais e econômicos de sua época, Verissimo (1973-1976, p. 307-314) dizia que um escritor não deveria estar a serviço de um partido político, mas aceitava os que assim o faziam, mesmo defendendo que um escritor devesse ser engajado com o homem e a vida, no sentido mais amplo e profundo dessas duas palavras. Dizia se manifestar sim, politicamente, sobre os problemas e acontecimentos sociais, de maneira coerente e inequívoca, contra qualquer forma de opressão e a favor dos direitos do homem. Erico considerava-se dentro do campo do humanismo-socialista, uma vez que dizia que o extremismo entre direita e esquerda ou centralização não the agradavam ao defender que era um erro imaginar que socialismo e liberdade eram ideias que se contradissessem, teorias que se transfiguraram em personagem como Dr. Rodrigo, em O Retrato.

Muitas são as considerações formuladas por estudiosos ao escritor e suas obras. No entanto, especificamente em Solo de Clarineta, o autor opera o que se pode nominar meta-literatura, isto é, conduz a narrativa de tal forma que o próprio autor tenha voz no texto literário. Neste sentido, Erico se descreve, diante do espelho, da seguinte maneira

Que penso de mim como escritor? Ora, depende da ocasião. Nos momentos escuros, minha tendência é considerar tudo quanto produzi até hoje medíocre ou mesmo mau. Nas horas claras, porém, olho com mais indulgência para os livros que até esta data escrevi, uns três ou quatro possuem alguma importância, e pelo menos um deles - creio que $O$ Continente - talvez me sobreviva por algum tempo.(ERICO VERISSIMO, 19731976, p. 314)

Levando em conta o fato de o romance histórico nascer durante o romantismo, invocando heróis primitivos e momentos culminantes da formação étnica brasileira, a presença do mito em $O$ Continente seria inevitável, embora, segundo ZILBERMAN, a intenção de Erico, descrita em suas memórias, fosse desmitificar a história sul-riograndense e não apenas autojustificá-la sob a perspectiva do mito. Como se comprova com o seguinte fragmento de Solo de Clarineta (1973, p.289): "Conclui então que a verdade sobre o passado do Rio Grande devia ser mais viva e bela que a sua mitologia. E quanto mais examinava a nossa História, mais convencido ficava da necessidade de desmitificá-la." Ao referir-se ao parentesco de $O$ Continente com o universo mítico, a estudiosa cita a construção dos heróis arquetípicos e míticos. Ela apresenta a personagem Pedro Missioneiro como um herói dotado de propriedades extraordinárias e sobrenaturais, retratando o início da família, transformada no princípio por excelência da sociedade humana, como fonte do estabelecimento da história do Rio Grande do Sul que é desencadeada por seu ato fundador.

Em seu segundo volume de Solo de Clarineta, organizado por Flávio Loureiro Chaves, Verissimo (1976, p. 319-323) questiona-se sobre que espécie de homem teria se tornado? Confessa que nem toda casa é um lar, o que explicaria sua tendência de ter do mundo uma visão plástica, e que nele, estaria associada à de casa - o conteúdo inseparável de $O$ Continente. Diz que não tem o menor apreço por condecorações: "Horroriza-me a ideia de ser transformado em medalhão. Não quero ser estátua, seja de busto ou de corpo inteiro. Não quero ser nome de praça ou rua. Não quero e não hei de me candidatar à Academia Brasileira de Letras." Novamente diante do espelho, sorri. Diz esperar ter ficado claro em suas memórias que, embora não seja por inclinação natural um homem de ação, é capaz de ação quando necessário.

O escritor diz ter omitido muitas peças, voluntária ou involuntariamente, no jogo de armar as histórias que ajudariam o leitor a encontrar uma resposta sobre quem era ou tinha se tornado. $\mathrm{Na}$ arte de dividir sua personalidade em duas ou mais partes, exercendo com frequência a faculdade de multiplicarse, diz $(1975,318)$ que Floriano Cambará, por exemplo, é seu irmão gêmeo, sósia. Diz sentir em si, todas as possibilidades para o bem ou para o mal, cometendo todos os pecados da imaginação - não 
apenas na fantasia, pois nem todas as coisas que aconteceram com Floriano, deveras aconteceram a ele, um contador de histórias. Concorda que o tédio Ihe ataca, como a Sartre, em que "o inferno são os outros", diz ter encontrado o lar perdido, ter descoberto que é o pai de si mesmo, e novamente diante do espelho: "Querias um concerto de jazz ou uma grande peça sinfônica. Eu te dei um solo de clarineta", "Se você[sic] não entendeu o que está escrito nas entrelinhas, a culpa não é minha".

Portanto, não é só o fato de Erico Verissimo definir-se como um contador de histórias, mas o modo como escreve e interpreta os fatos do mundo. Erico é uma espécie de Narciso confesso, que dialogando com sua imagem diante do espelho, apresenta os fatos para depois aprofundá-los, usando a mesma estratégia narrativa de um contador de histórias, ou seja, apresenta os relatos, dotados de tensão e clímax, em forma de capítulos e subcapítulos, como faz com a estrutura de $O$ Continente $I$, fato que é semelhante em outras de suas construções, onde, independente do enunciado, usa sempre a mesma enunciação, mesmo que sejam conteúdos diferentes com o mesmo jeito de contar histórias, mas permeadas pelo mito e pelo imaginário.

\section{A construção do universo mítico: uma visão sobre a narrativa e seus personagens}

Como já dito, Erico Verissimo, em O Tempo e o Vento, apropria-se dos recursos da mitologia e da simbologia, das informações históricas e filosóficas e outras como fonte de inspiração. A apresentação desse procedimento toma para si a proposta de utilização de fatores estéticos mais relevantes da literatura gaúcha, dando ênfase a temas como espaço, tempo, temática e mitologia.

Observa-se na obra de Verissimo, o surreal como o ponto de encontro entre a realidade e o imaginário, ou seja, mesmo que a obra tenha efeitos de sentido reais, referências históricas, usando personagens da história do Rio Grande do Sul e do Brasil, ocorre uma anulação desses dados anteriores à obra, como se esses nomes apenas sobreviveram no mundo da surrealidade, ou ao contrário, esses personagens fizessem parte do real, do cotidiano. Essa linguagem, encontrada no literário, que faz referência dos dois mundos, é teorizada por Jozef

[...] O fantástico, como categoria do literário, é um discurso que coloca em discussão a lógica da realidade compreendida como real, acusando as contradições do mundo contemporâneo.. Desde Saussure sabemos que a linguagem pertence à ordem simbólica( isto é, mundo de cultura e da civilização) e dentro dela efetua-se um sistema que contraria as próprias regras do simbólico: a do imaginário. $\mathrm{Na}$ literatura fantástica não se trata de crer no real para reconhecer o imaginário, mas tomar por imaginário o real que recusamos a assumir.[...](1986, p. 219).

Tem-se assim, uma definição do fantástico, ao qual muitos escritores iram se referir ao comentar as obras de Erico Verissimo, através da percepção particular de acontecimentos estranhos, pois o leitor ao entrar na narrativa, vendo o mundo presente como real, identificando-se com os personagens e com os fatos históricos e ficcionais, se obriga a considerar o mundo das personagens, fazendo a ligação entre esses dois universos.

Não apenas através de um personagem, mas pelo enredo, ou temática da obra, essa identificação, pode levar o leitor a entrar em conflito com a realidade e a fantasia. Como exemplo, temos o primeiro capítulo de $O$ Continente $l$, onde os personagens ficcionais de Erico transitam livremente nas Ruínas Jesuíticas, fazendo com que o leitor realmente acredite que Pedro Missioneiro tivesse vivido entre os corredores das reduções de São Miguel Arcanjo.

Ainda assim, Marobin (1995, p.265) afirma que a obra literária de Verissimo, a qual ocupa lugar de grande destaque no quadro geral da literatura do Rio Grande do Sul, traça "vasto painel da realidade gaúcha" apresentando o espaço - pensar e sentir do povo rio-grandense - e horizontes como o regional e o universal. $\mathrm{O}$ autor afirma que são a fábula, o mito e o maravilhoso que formam o fundo temático da trilogia de Erico.

Como face externa do romance, Marobin (1995, p. 265) salienta que é o horizonte regional, 
envolvendo pampa, coxilhas, querência e os próprios personagens-heróis que moldam o gaúcho como "novo Orfeu ou como centauro dos pampas e monarca das coxilhas". No entanto, as faces ocultas são ainda mais ricas, uma vez que envolvem o homem em circunstâncias concretas de espaço, com seus sonhos, anseios, utopias, mitos, mistérios e histórias.

Marobin (1995, p.265) apresenta as fontes de inspiração do romancista Erico Verissimo, como se as mesmas se limitassem a estar fortemente vinculadas aos cinco sentidos, usando estes como ponto de partida. $O$ pesquisador conclui alegando que no mundo imaginário, o espírito não tem fronteira. Para o autor (1995, p. 266) essas fontes podem ser ordenadas em dois grupos: no primeiro encontramos a importância da casa, do campo, da história, do gaúcho rio-grandense e seus costumes regionais; no segundo, Erico se torna mais livre de limitações físicas, abrindo assim, novas possibilidades dos tipos ideais, abstratos e arquetípicos.

Marobin (1995, p.267) ainda descreve a presença quase obsessiva da ideia de casa e sobrado em $O$ Continente, ocupando seis longos capítulos, onde o narrador vai construindo a ideia de sobrado como externa e interna. A primeira estaria ligada ao fato de abrigar os personagens das ações naturais, como fortaleza contra os inimigos e lugar de moradia; enquanto a segunda, representaria o mítico, o simbólico e o arquetípico, como a mente, em sua face mais oculta.

Como fator representativo da faceta externa, com duas descrições físicas; e internas: com a aproximação do sobrado com características humanas, temos 0 seguinte fragmento de $O$ Continente I (p. 22): [...] fechou o olho direito e com o esquerdo ficou espiando o Sobrado que lá estava, do outro lado da praça, com sua fachada branca, a dupla fileira de janelas, a sacada de ferro e os altos muros de fortaleza. Havia no casarão algo de terrivelmente humano que fez o coração de José Lírio pulsar com mais força". Conforme Marobin (1995, p. 267), o sobrado representa na narrativa mais que moradia, lugar onde as pessoas nascem, vivem e morrem, ele é também fortaleza (como podemos observar do ponto de vista do narrador ao retomarmos a citação anterior), proteção contra o vento minuano dos gélidos invernos e contra o ataque em época de sítio inimigo.

Para Chevalier (2003, p. 197), em Dicionários dos Símbolos, "A casa significa o ser interior; seus andares, seu porão e sótão simbolizam diversos estados da alma. O porão corresponde ao inconsciente, o sótão à elevação espiritual. A casa é, também, um símbolo feminino, com o sentido de refúgio, de mãe, de proteção, de seio maternal".

Por seu turno, Marobin (1995, p. 267) ensina que o sobrado representa a face oculta, sendo consoante à Chevalier ao relacioná-la à mente como ponto de partida. Podemos tomar como análise o desenvolvimento da narrativa da trilogia de Erico em O Tempo e o Vento, ao relembrarmos que foi no porão que a filha de Alice e Licurgo, a qual nascerá morta, foi enterrada, na ocasião em que o sobrado estava sitiado, e que também, usando como cenário para construção de uma produção de sentido, era no sótão do mesmo sobrado que $\circ$ Dr. Rodrigo Cambará gostava de passar horas de seus dias, compondo a complexidade de seu personagem em $O$ Retrato.

Em suas memórias, Verissimo (1976, p. 300) descreve a presença do Sobrado em sua obra "Outra personagem importante de O Tempo e o Vento é o Sobrado, que sinto como um ser vivo e quase pensante. É, evidentemente, um símbolo uterino, materno e - pode também ser uma recriação idealizada do lar que eu perdera e ainda buscava".

Após descrever a constante presença da figura do sobrado na obra de Erico, Marobin (1995, p.268) justifica que essa retomada é, em verdade, uma necessidade de proteção de casa paterna e materna, de abrigo de corpo e de alma que acompanha Erico Verissimo, sendo a temática campo, a fonte de inspiração do escritor em $O$ Continente. Neste quesito,Marobin (1995, p. 268), contrasta a proteção do sobrado, com a liberdade do campo, pondo em 
destaque o fato de campo, coxilha e terra trazerem ao gaúcho, conotação de posse e vida.

Ele também diz que a inspiração ligada ao campo é telúrica, com um espaço para a criação de gado e plantio de sementes e outro para as divagações da fantasia. Para Marobin (1995, p.269), o termo terra, em $O$ Continente, tem conotação de liberdade, vastidão, por ter como cenário campinas desertas, somado ao fato desta terra ter sido, desde os primórdios do continente da Província de São Pedro, tratada como terra de todos, dada por Deus, como propriedade. A ideia pode ter como fonte a raiz mítica e divina, sendo posteriormente transformada em horizonte político e econômico, porque é ainda em torno dessa mesma terra, por fronteiras e demarcações que é travada nova disputa, inspirando Erico, segundo Marobin, no sentido da realidade concreta e do mundo imaginário. Marobin (1995, p. 269) ainda afirma que o resultado mais notável da presença do campo como fonte inspiradora para Erico são os sobrenomes dos próprios personagens: Terra e Cambará

Ao se referir à história como fonte de inspiração, Marobin (1995, p. 270) é incisivo ao dizer da importância dessa fonte, relacionando-a à época da atividade intelectual de Erico em Porto Alegre, a qual coincidia com o Centenário Farroupilha de 1935. Afirma que esses saraus literários com grandes estudiosos da época, dos quais Erico participou, possam ter contribuído significativamente à consolidação da obra do escritor, já que ele apresenta plena consciência do que é histórico e estórico, fábula, trabalhando sob o viés da criação alicerçado em fatos que poderiam ter acontecido exatamente naquela época.

Ainda Marobin (1995, p.272) segue retratando O Continente sob a ótica do gaúcho rio-grandense. Segundo ele, a mais rica inspiração de Erico Verissimo. O autor diz que esse tipo de gaúcho-tipo permanece vivo no subconsciente do povo dos pampas, como as personagens Ana Terra e Capitão Rodrigo. A imagem de gaúcho inspirador, defendida por Erico, conforme apresentação de Marobin, é a "ideia de que o homem deve ser, antes de tudo, livre, honesto e honrado". Para ele (p.273) Erico respeitou a História, mas também respeitou o escritor.

$\mathrm{Na}$ verdade escritores, como Arthur Ferreira e Aurélio Porto, por exemplo, já haviam interpretado a história do RS. Entretanto, segundo Marobin (1995, p. 273) , O Continente destacagaúchos-símbolos criados por Erico Veríssimo, como Ana Terra e Pedro Missioneiro, com fortes características dos habitantes da fronteira, que através da capacidade de Erico de dosar realidade e fantasia, dividem cenários com personalidades conhecidas da História, Bento Gonçalves e Pinto Bandeira, por exemplo, através de uma linha de limite entre literatura e história é muito tênue.

Marobin (1995, p. 274) ainda chama a atenção quanto ao uso dos costumes caseiros, do dia-a-dia, como fonte de inspiração de Erico Verissimo, esses são tratados ora de forma robusta; ora lírica, no desenvolver da narrativa e na caracterização de cada personagem, quanto aos seus trajes, atitudes e costumes, como exemplo podemos usar a máxima cunhada pelo personagem Capitão Rodrigo: "Buenas e me espalho! Nos pequenos dou de prancha e nos grandes dou de talho!", que denota sua postura perante os demais. (VERISSIMO, 2004, p. 209)

Após tratar das fontes regionais de inspiração para Erico Verissimo, Luiz Marobin (1995, p. 276) descreve o universo das possibilidades abstratas, dos modelos perfeitos, que abrangem fonte de inspiração em $O$ Continente, as quais podemos destacar o mito, a religião e o subconsciente individual e coletivo. Ao se referir diretamente a mito, Marobin (1995, p. 276) explica que na cultura grega, o mesmo era narração, fábula, quimera, coisa impossível, mas também um recurso de linguagem e que, como hoje, usamos para explicar algo que transcende os cinco sentidos e a imaginação. Como exemplos da presença do mítico em $O$ Continente $I$, podemos citar a Lenda da Salamanca do Jarau, que é narrada pela personagem Pedro Missioneiro.

Em Verissimo (2004, p. 81) consta que "Santa Fé é...uma dádiva do Todo Poderoso". Com a fala pronunciada pelo padre Atílio Romano, personagem de "O Continente II", Marobin (1995, p.279-283) 
caracteriza a religião, também considerada fonte de inspiração de Erico Verissimo. O autor diz que a ideia de Deus abarca o problema da existência da mesma e do relacionamento com as personagens. E conclui dizendo que a religiosidade na obra aparece de diversas maneiras, tanto nas pregações dos sacerdotes, como no linguajar do povo.

Embora a religiosidade apareça de diferentes formas na construção de $O$ Continente, em suas memórias, Verissimo (1973-1976, p. 311-312) é taxativo ao dizer ter dificuldade em explicar a amigos e leitores a sua posição em face de Deus. Erico se define como agnóstico, ou seja, "um homem que não se encontra na posse de provas convincentes que the permitam negar ou afirmar a existência dum Criador." Contudo, diz que não é destituído de sentimento religioso, pois possui um verdadeiro e cordial respeito por todas as formas de vida, e grande repúdio à violência. $O$ escritor diz sentir grande afeição e admiração pela figura de Cristo e acredita que se a ética cristã é posta em prática, sendo que as criaturas humanas poderiam resolver seus problemas de convivência. Entretanto, diz não aceitar as "fábulas bíblicas" e suas ideias de Paraíso, pecado original e Santíssima Trindade, por exemplo, pois segundo ele, aceitar o mito de que quem faz boas ações em terra, ganhará o céu, fantasiados de anjo, seria fazer pouco caso da imagem de Ente Superior.

E encerrando suas considerações sobre as fontes regionais e universais de inspiração em " $\mathrm{O}$ Continente I" , na descrição do subconsciente individual e coletivo, Marobin (1995, p. 283-284) trata sobre o processo de elaboração do romance. Diz que o subconsciente individual de Erico se manifesta de muitas maneiras, através de mitos, lendas e personagens, como Floriano, considerado pelo ensaísta, alter ego de Erico. Enquanto o subconsciente coletivo se manifesta no folclore, na cultura popular, nas tradições, crenças e crendices, como: "perfis de heróis, cenas de fantasmas, aparições de monstros noturnos, cobras de fogo"

Em síntese, Marobin (1995, p. 284-285 ) afirma que Erico Verissimo foi um escritor de grande talento, com fontes de inspiração que provinham do campo e da cidade, retratando não só personagens imortais, como também o povo do pampa e o próprio Rio Grande do Sul.

\subsection{A construção da narrativa e dos personagens em $O$ Continente I}

Está evidenciada a existência de relação entre a mitologia regional e universal no romance de Erico Veríssimo, pois reconhecer os momentos em que a narrativa histórica e mitológica estabelecem um caráter dialógico, para o leitor supostamente 'leigo' desta comédia provinciana, é um tanto complexo, já que essa semelhança, quase confusa, entre personagem real e ficcional tende a se tornar quase imperceptível.

Segundo Brait (2004, p. 29), até meados do século XVIII os estudos empreendidos por Aristóteles serviram de modelo para que a concepção de personagem, com seu conceito de mimesis, fossem definidas. No entanto, alguns séculos depois, a visão de personagem como imitação, estabelecida por Aristóteles é substituída, conforme diz Brait, por uma visão psicologizante, a qual entende personagem como a representação do universo psicológico de seu criador, ou seja, os seres fictícios passam a serem vistos, não mais como uma imitação do mundo exterior, mas como uma projeção da maneira de ser do escritor.

Brait (2004, p. 40), evidencia a relação que os personagens possuem com as demais partes da obra, resultando em classificações como: personagens planas e redondas. As personagens planas são aquelas construídas ao redor de uma única ideia ou qualidade, definidas em poucas palavras e sem evolução no decorrer da narrativa, sem surpresas ao leitor, como D. Henriqueta, mãe de Ana Terra, mulher serena e aparentemente triste, a qual o narrador acrescenta (VERISSIMO, 2004, p.109): "D. Henriqueta respeitava o marido, nunca ousava contrariá-lo". 
Já as personagens redondas são aquelas marcadas por sua complexidade, apresentando várias qualidades e tendências e surpreendendo o leitor. Essas personagens são dinâmicas, constituindo, muitas vezes, imagens particulares do ser humano, o que referenciando à obra verissimiana permite compará-la, por exemplo, à personagem de Capitão Rodrigo, que embora não muito complexo como os personagens de grandes clássicos, surpreendia 0 leitor com suas atitudes clássicas do personagem tipo, que ia se construindo e definindo sob a ótica da interpretação particular.

Apresentando a personagem não apenas como um domínio exclusivo da literatura, mas com uma visão pautada na divisão semântica, sintaxe e pragmática preconizada por Philippe Hamon', Brait (2004, p. 45), define três tipos de personagens: as personagens referenciais, que remetem a um sentido pleno e fixo, chamados de personagens históricos, os quais são imobilizados por uma cultura, assegurando o efeito do real e contribuindo para que esses personagens sejam designados heróis, como Pedro Missioneiro e Capitão Rodrigo Cambará; personagens embrayeurs, funcionando como elementos de conexão, dependendo de outros elementos na narrativa para ganharem sentido; e personagens anáforas, que, segundo Brait (2004, p. 46), "São aqueles que só podem ser apreendidas completamente na rede de relações formadas pelo tecido da obra". Para Brait (2004, p. 68), qualquer tentativa de definição de estrutura de personagens esbarra na questão do narrador, pois o mesmo funcionará como um ponto de vista capaz de caracterizar o personagem, dando ao leitor a impressão de terem existido em uma dimensão que ultrapassa a ficção. Cabe dessa forma, a sensibilidade do autor, possibilitar a existência de suas criaturas de papel, as quais, muitas vezes, fogem do seu domínio e permanecem na imaginação dos leitores. Brait (2004, p.68-69) conclui "que a criação do personagem obedece a determinadas leis, cujas pistas só o texto pode fornecer", sendo que ao

${ }^{1}$ A fonte original pode ser encontrada em: Litteraturé, 6 :86-110. 1972. se analisar a construção do personagem em determinada obra, faz-se necessária uma intensa análise ao seu caráter parcial para que o trabalho do escritor não seja meramente reduzido e classificado.

Já que para Brait (2004, p. 67), a personagem, ainda que classificada, dependa da técnica que o autor irá usar para apresentá-la segundo suas intenções de catarse no leitor, faz-se necessário que se entenda como a narrativa construída envolverá essas personagens e as defini-las em relação às demais. Conforme afirma Azevedo (2001, p.143), a trilogia O Tempo e o Vento é apresentada em terceira pessoa, como narrador onisciente, classificação essa que, segundo Leite (1992, p.47) sob a óptica da tipologia de Norman Friedman ${ }^{2}$, pode ser relacionada à teoria que estabelece o papel do narrador como onisciência seletiva múltipla, uma vez que não há alguém que narra, pois a história é contada através das personagens, de suas impressões deixadas. Para Leite (2002, p. 47): "[...]o autor traduz os pensamentos, percepções e sentimentos filtrados pela mente dos personagens, detalhadamente.".

Ainda, conforme Azevedo (2001, p.143), a onisciência do narrador, em $O$ Continente $I$, relata os diversos acontecimentos que formaram o Rio Grande do Sul e as relações dramáticas de seus habitantes através dos personagens de ficção e reais, como os coronéis e políticos envolvidos no enredo. Como exemplo de uma cena em que há o deslizar do interior para o exterior mostrando o processo mental da personagem, sendo traduzido através de suas ações, pode-se transcrever a reação de Ana Terra ao nascimento de Bibiana, sua neta ( Verissimo, 2004, p.186 ) "No inverno de 1806 Ana ajudou a trazer para o mundo seu segundo neto, uma menina que recebeu o nome de Bibiana. Ao ver-lhe o sexo, a avó resmungou: 'Mais uma escrava'. E atirou a tesoura em cima da mesa num gesto de raiva e ao mesmo tempo de alegria".

\footnotetext{
${ }^{2}$ A fonte original pode ser encontrada em: FRIEDMAN, Norman. Point of View in Ficticion, the development of a crtitical concept. In: STEVICK, Philip, ed. The Theory of the Novel. New York. The Free Press, 1967.
} 


\subsection{Ana Terra e Pedro Missioneiro como personagens épicas e míticas}

Sempre que me acontece alguma coisa importante, está ventando, dizia Ana Terra.

Erico Verissimo

Era pura teimosia, a sorte parecia insistir em lutar contra a personagem. Tinha muita vontade de viver, embora soubesse que nunca mais iria rir ou chorar. "Chamava-se Ana Terra. Tinha herdado do pai o gênio de mula"(VERISSIMO, 1995, p.71). Havia enterrado os pais e os irmãos, não tinha casa e nem nada que a pudesse prender às terras no Continente onde fora criada depois de vir de Sorocaba com a família, com as cruzes que ficaram para traz, Ana Terra pontilhou seu passado, e de carona com uma família que passou pela estância rumou com os seus, para as terras do coronel Ricardo Amaral, iria começar uma nova vida, levara o punhal de prata, o Cristo de nariz carcomido, a roca, a tesoura de podar, - coração cheio de amarguras, e uma imensa vontade de viver, por e para Pedrinho, pois como ela mesma havia concluído: "por piores que fossem as coisas que estavam por vir, não podiam ser tão horríveis como as que já tinha sofrido."(VERISSIMO, 1995, p.70).O início da trajetória da personagem Ana Terra, que no limite mais dramático e profundo, com seus valores, representa todas as mulheres no romance, é descrita da seguinte forma

Em Ana Terra o espaço físico foi interamente detruído após um ataque de castelhanos, que massacraram todos os homens válidos da fazendo de Maneco Terra. Então, sob a imensidão do campo, duas mulheres e as crianças sepultam seus mortos, nascendo daí a personagem Ana Terra, armada de uma confiança extraordinária de si mesma, que se integra na caravana pioneira para fundar, muito distante, a vila de Santa Fé, a cidadesímbolo do início do Rio Grande do Sul. (GILMAR AZEVEDO ,2001, p. 81-113)

Para Azevedo (2001, p. 113) Ana Terra representou o estereótipo da mulher sul-riograndense, encarnando o patriarcalismo exagerado, o qual estabeleceu a obediência submissa da mulher, o que se comprova com o seguinte fragmento na fala de Ana (VERISSIMO, 1995, p. 195): "Guerra era coisa de homem; carreira, briga, jogo e bebida eram coisas de homem. O melhor que as mulheres tinha a fazer era desistir de compreendê-los. Desistir e continuar obedecendo e esperando[...]". O mesmo autor ainda afirma que embora essas características sejam expressas com 0 comportamento da personagem, é inegável o paradoxo existente, uma vez que a força da personagem representaria o heroísmo que os homens não viram ou tiveram medo de admitir, força essa que era construída através do símbolo de amadurecimento de Ana, como filha, irmã, amante, mãe, avó e mulher e de seus sentimentos mais fortes: solidão, fogo, paixão e medo.

A análise feita por Zilberman (1992, p. 74), refere-se ao início da família com a personagem Pedro Missioneiro, que segundo a escritora é dotado de "propriedades extraordinárias, com uma sobrenaturalidade peculiar aos heróis míticos", que faria a genealogia prosseguir, contando a história e a origem de diversos clãs, assemelha-se à teoria estabelecida por Eliade (1972, p. 26), quando aborda mitos de origem e mitos cosmogônicos no capítulo denominado Prestígio Mágico das Origens: "Todo mito de origem conta e justifica uma "situação nova" nova no sentido que não existia desde o início do Mundo (grifo do autor). Os mitos de origem prolongam e completam o mito cosmogônico: eles contam como o mundo foi modificado, enriquecido ou empobrecido.

Outro aspecto que Zilberman (1992, p 74) considera é o fato de que "os descendentes dos heróis míticos reproduzem física e intelectualmente os ancestrais", como os amores proibidos das diversas gerações: Pedro-Ana, Rodrigo-Bibiana, Bolívar-Luzia, etc., havendo semelhante situação relacionada ao nascimento de uma criança seguida da morte de seu pai nas diversas gerações da família.

Ainda sob a esteira de Eliade (1972, p. 26), pode-se afirmar que a repetição é própria à estrutura do mito, a qual sempre retorna ao momento da criação, o que esclarece o desenvolvimento do clã da 
família Terra Cambará, quando se repete à história vivida por Pedro Missioneiro, que dá origem à genealogia de Ana Terra com o nascimento de seu filho após morte de Pedro Missioneiro. Ainda, conforme Zilberman (1992, p.75), esses aspectos retomam o mito de origem que se identifica com 0 início do mundo, pois O Tempo e O Vento retrata a conquista do território ligando à própria terra, ao homem e seu filho. Zilberman, nesse contexto, faz alusão aos sobrenomes das personagens das famílias condutoras da história: os Terra (solo) e os Cambará (árvore-natureza-solo).

Para Mircea, (1972, p. 164), pode-se observar, na literatura, uma revolta contra o tempo histórico, ou seja, um desejo de atingir outros tempos, distintos dos que somos obrigados a viver, como um desejo de reencontrar a intensidade com que se viveu ou se conheceu alguma coisa pela primeira vez, recuperando o passado em uma luta de se libertar do próprio tempo.

Para Dacanal ( 1982, p. 53), é possível afirmar que o romance de Erico Verissimo começa a decair quando aborda temas mais próximos à realidade, como se realmente o autor quisesse reviver um passado original que estava se perdendo. Outrossim, pode-se relacionar a seguinte abordagem temporal

$\mathrm{Na}$ obra de Erico Verissimo existe uma estreita vinculação entre o conceito de Tempo e o do Vento[...].Existem dois tempos: um é o físico, objetivo, que se dá aqui e agora. Outro é o psicológico, atemporal, digamos. A necessidade e ansiedade de prender o tempo físico transformando-o em tempo psicológico ordena, em última análise, a literatura de Erico Verissimo, para quem o tempo cumpre diferentes funções na vida humana. (HOHFELDT, 1984, p. 52)

Para Hohfeldt (1984, p. 52), essa análise de tempo se destaca na perspectiva das mulheres que, por ocasião das guerras, ficam em casa a fiar em sua roca, como Ana Terra e Bibiana e a esperar que o tempo, inflexível e irreversível, deixe de ser uma repetição do dia anterior, como afirma o próprio narrador quando Pedro, filho de Ana parte com as tropas de Chico Amaral para reunir-se às forças de Mena Barreto: "E de novo o povoado ficou deserto de homens. E outra vez as mulheres se puseram a esperar" em Verissimo (2004, p.189).

Conforme Hohfeldt (1984, p.54) existe uma relação importante entre os objetos símbolos da obra que costuram o religioso e o sobrenatural, como exemplo utiliza a expressão usada pelo personagem Floriano, altor ego de Erico: "Pai era vento. Mãe era terra". Explica que o tempo, em várias línguas é uma palavra feminina, é um elemento representativo da vida fazendo assim relação às mulheres, ele se constrói verticalmente, designando conservação , cujo símbolo na obra é a tesoura que as mulheres usavam para cortar o cordão umbilical das crianças ao nascerem, representando propriedade e a vida. Enquanto o vento é representativo da morte, dessa forma masculino. Ao contrário do tempo, ele se constrói, na perspectiva de Hohfeldt, horizontalmente, simbolizando conquista e posse através do personagem Capitão Rodrigo por exemplo, tendo como símbolo básico o punhal de Pedro Missioneiro que passa de geração em geração através de seu clã fazendo referência a figura masculina.

As mulheres, principalmente Ana Terra, têm por companhia na caverna que as abriga, o tempo que as faz esperar por seus maridos, irmãos e filhos voltarem das guerras e revoluções. Estão presas à terra, como sugere a própria etimologia do nome Ana, que vem do hebraico e quer dizer terra, sugerindo um jogo de palavras: Ana Terra/terra Terra. Para representar a espera, fortaleza e permanência, Ana torna-se, transmissora de elementos familiares básicos e, até mesmo, é interpretação relacionada às raízes na terra, fertilidade, procriação ligadas à personagem, matriarca dos "Terra".

Já as personagens masculinas possuem 0 vento como simbologia, que as leva e traz, como a personagem Horácio, irmão de Ana, que era o único a sair da suposta "caverna", quando ia a Rio Pardo fazer compras, representando a conquista e o desbravamento, ligados também à faca (punhal de Pedro), simbolicamente masculina, relacionadas à força, coragem, instrumento da lida campeira, na carneação de gado, por exemplo, ou nas revoluções 
9

com as armas brancas, na defesa de suas terras e interesses políticos.

\section{Conclusão}

Ao longo do estudo, analisando o conceito de gaúcho literário/mitológico aplicado à obra $O$ Continente I - alicerçado em teorias apresentadas por filósofos e críticos - foi possível observar que muitos escritores ainda defendem que a mitologia foi uma forma encontrada pelo povo gaúcho e pela literatura, de se auto-justificar, explicar alguns fatos da realidade enquanto outros dizem que não passa de um recurso estético, tornando complexas personagens planas e redondas, para ratificar o que transcende aos cinco sentidos. Concluí-se que o povo sulino fazia das lidas comuns de campo, trabalhos de ambiência com a natureza - terras, animais, vegetais - sem se importar se isso iria mudar seu caráter ou não, referenciando o discutido durante o trabalho sobre o fato do romancista não ter acesso ao tempo primordial dos mitos, mas ao contar uma história verossímil, passava a utilizar um tempo aparentemente histórico.

Não havia uma análise de conduta entre os habitantes de Rio Grande do Sul, diferentemente do que acontecia com os personagens de Santa Fé. O povo sulino fazia e se portava de determinada maneira, porque estava dividido em clãs que exigiam - para sua sobrevivência, pela lei da natureza - que se comportasse dessa forma, retomando novamente o mito de origem ou cosmogônico. Erico mostra, dessa forma, a ascensão e a decadência desse conceito de gaúcho ao estabelecer relação entre história e ficção. O que sobra desse ponto de encontro, dessa fusão, é o texto literário. Alguns autores dizem que Erico usava os cinco sentidos para criar seus personagens e suas narrativas, tanto é que podemos perceber em $O$ Continente, como constrói os cenários, como manipula seus bonecos e como brinca de Deus, em Santa Fé.

Há de se admitir que o gaúcho existiu, foi idealizado em prosa e verso por escritores ufanistas, folcloristas e professores, oradores cívicos e políticos,e hoje ele ainda existe, mas já diferenciado do arquétipo. Com as observações de Erico, percebese essa diferença, do gaúcho épico, idealizado, o qual iremos reconhecer na construção que Erico faz de seus personagens em $O$ Continente $I$, para os gaúchos modernos, normais como qualquer brasileiro. Deixou de se ver o sul-rio-grandense com complacência narcisista, como protótipo de um povo, e passou-se a analisar as marcas deixadas por esse tipo rural, como seus hábitos, linguajar, impulsos e sentimentos

E é nessa imbricação simbólica e factual que a instigação mítica se constrói e se explica, servindo como modelo para a conduta dos gaúchos tradicionais, onde as experiências eram tidas como verdadeiras e repassadas através das gerações, dando continuidade a uma tradição, que é apresentada como um fenômeno de cultura, cuja manifestação é, de certa forma, transposta para a estrutura épica de $O$ Continente $I$.

Ao abordar o povo sul-rio-grandense, Erico retrata um homem forjado pelo trabalho árduo do campo e pela necessidade da guerra, sempre em contraponto a outros que se detinham ao patriarcado rural e à burguesia da indústria, dando vida às personagens construídas sob a ótica de grandes nomes da história do Rio Grande do Sul, como Bento Gonçalves e Getúlio Vargas.

Dessa forma, o mito vai sendo estabelecido na retomada do regionalismo que cria um personagem socialmente estereotipado para representação patriótica sul-rio-grandense: o gaúcho. O homem, principalmente o sul-rio-grandense, não vive sem o mito, talvez por medo de perder suas referências, as marcas do passado que o caracterizam ou simplesmente se desorientar psicologicamente, esclarecendo, assim, o uso desse recurso mitológico em sua trajetória folclórica e histórica como recurso artístico, real e em contraponto ficcional. Recurso esse, que Erico Verissimo apropriou-se para compor $O$ Continente $I$, sem a pretensão de traçar taxativamente um perfil de uma época e de um povo, 
nem reproduzir documento histórico, mas para estudar e compreender uma narrativa tão envolvente, com personagens dotadas da mais profunda complexidade e humanidade.

\section{Referências}

AZEVEDO, Gilmar de. Na Pele da Imagem: o mito do gaúcho em O Tempo e o Vento. Passo Fundo: UPF, Editora Universitária, 2001.

BARTHES, Roland. Introdução estrutural a análise da narrativa. Cidade: Editora, 1976.

BRAIT, Beth. A Personagem. São Paulo: Ática, 1986.

CHAVES, Flávio Loureiro. Erico Verissimo: Realismo \& Sociedade. $2^{\circ}$. Ed. Porto Alegre: Mercado Aberto, 1971.

O narrador como testemunha da história. In GONÇALVES, Robson Pereira (Org.) OTempo e o Vento: 50 anos. Santa Maria: Ed. UFSM; Bauru; EDUSC, 2000.

Letras Rio-Grandenses - Simões

Lopes Neto. Porto Alegre: IEL, 1987.

CHEVALIER, J.; GHEERBRANT, A. Dicionário de símbolos. 11. ed. Rio de Janeiro: José Olympio, 2003

DACANAL, José Hildebrando. O Romance de 30. (Revisão 7) Porto Alegre: Mercado Aberto, 1982.

ELIADE, Mircea. Mito e Realidade. Trad. Polla Civelli. São Paulo: Perspectivas S.A.; 1994.

Aspectos do Mito. Rio de Janeiro:

Perspectivas do homem/Edições 70, 1963.

HOHFELDT, Antonio. Erico Verissimo.Coleção 'Esses Gaúchos'. Porto Alegre: Tchê, 1984.

JOSEF, Bella. A Máscara e o Enigma. Rio de Janeiro: Livraria Francisco Alves Editora S.A., 2006.

LEITE, Ligia Chiappini Moraes. O foco narrativo. São Paulo: Ática, 1997.

FREIRE MAIA, Newton. Teoria da evolução:de Darwin a teoria sintética. Belo Horizonte: Itatiaia, 1988.

MAROBIN, Luiz. Painéis da literatura gaúcha. São Leopoldo: Ed. UNISINOS, 1995.

REVERBEL, Carlos. O Gaúcho: Aspectos de sua formação no Rio Grande e no Rio do Prata. Porto Alegre: L\&PM Editores Ltda, 1986.

VERISSIMO, Erico. O Tempo e o Vento [parte I]. O Continente vol.I. Editora Scharcz, 2004.
O Continente. Vol. 1. 3ํㅡd. São

Paulo: Companhia das Letras, 2004.

O Continente. 31. Ed. São Paulo:

Solo de Clarineta: memórias. 10. Ed. V.1-2. Porto Alegre: Globo, 1976.

Solo de Clarineta: memórias. 10. Ed. V.2 "Segunda parte, póstuma organizada por Flávio Loureiro Chaves". Porto Alegre: Globo, 1976.

ZERO HORA. Todos os tempos de Erico Verissimo. Porto Alegre: Grupo RBS, agosto de 2004. Segundo Caderno - Cultura.

Todos os tempos de Erico Verissimo. Segundo Caderno - Cultura. Porto Alegre: Grupo RBS, 28 de agosto de 2004, p. 04-06.

ZILBERMAN, Regina. Roteiro de uma literatura singular.Porto Alegre: Ed. UFRGS, 1992.

HAMON, Philippe. Litteraturé, 6 :86-110. 1972.

FRIEDMAN, Norman. Point of View in Ficticion, the development of a crtitical concept. In: STEVICK, Philip, ed. The Theory of the Novel. New York. The Free Press, 1967. 